\title{
STATISTICAL ANALYSIS OF THE CASUISTRY OF A SAMPLE OF METASTATIC DISEASE IN THE SPINE
}

\author{
ANÁLISE ESTATÍSTICA DA CASUÍSTICA DE UMA AMOSTRA DE DOENÇA METASTÁTICA NA \\ COLUNA VERTEBRAL
}

\section{ANÁLISIS ESTADÍSTICO DE LA CASUISTIICA DE UNA MUESTRA DE ENFERMEDAD METASTÁSICA EN LA COLUMNA VERTEBRAL}

David Marcelo Duarte1', Raphael de Rezende Pratal1', André Luiz Pellacani França1', Carlos Eduardo Algaves Soares Oliveira1

1. Hospital do Servidor Público Estadual de São Paulo, São Paulo, SP, Brazil.

\begin{abstract}
Objective: The objective of this study is to present demographic data on the occurrence of spinal metastases in the service where the work was performed and to investigate the reliability of the modified Tokuhashi score in the decision making in patients with metastatic spinal cancer. Methods: We conducted a review of medical records of all cases of vertebral bone metastasis, confirmed by anatomopathological examination, from January 2009 to June 2012. Data review included demographic details, origin of the primary cancer, duration of symptoms, localization of metastases, Karnofsky performance scale and survival based on modified Tokuhashi score. We divided patients into three groups. Group A included patients with life expectancy of less than six months, group B included patients with life expectancy of between six and 12 months, and group $C$ included patients with a life expectancy of more than 12 months. We compared the calculated survival with the current survival in the three groups with all patients followed-up to a minimum of 1 year or until death. Results: The predict survival in group A was 63.6\% according to the modified Tokuhashi score, albeit group B had only $30 \%$ agreement. Conclusions: For patients in group A, the agreement rate of patient survival was better (63.4\%) than that observed in patients in group B (30\%). Our sample had no patient classified as group C.
\end{abstract}

Keywords: Spine; Neoplasm metastasis; Bone and bones; Survival analysis; Demographic data.

\section{RESUMO}

Objetivo: O objetivo do trabalho é apresentar dados demográficos sobre a ocorrência de metástases na coluna vertebral no serviço onde o trabalho foi realizado e investigar a confiabilidade do escore modificado de Tokuhashi no processo de decisão em pacientes com câncer metastático na coluna. Métodos: Realizamos uma revisão de prontuários de todos os casos de metástase óssea vertebral, confirmadas por exame anatomopatológico, no período de janeiro de 2009 a junho de 2012. A revisão de dados incluiu detalhes demográficos, origem do câncer primário, duração dos sintomas, localização das metástases, escala de performance de Karnofsky e cálculo da sobrevida com base no escore modificado de Tokuhashi. Dividimos os pacientes em três grupos. O grupo A incluiu pacientes com expectativa de vida menor do que seis meses, grupo B incluiu pacientes com expectativa de vida entre seis e 12 meses e grupo C incluiu pacientes com expectativa de vida maior que 12 meses. Comparamos a sobrevida calculada com a atual sobrevida nos três grupos, com todos pacientes acompanhados até o mínimo de um ano ou até a morte. Resultados: A sobrevida prevista nos pacientes do grupo A foi de 63,6\% de acordo com o escore modificado de Tokuhashi, contudo pacientes do grupo B tiveram apenas 30\% de concordância. Conclusões: Para pacientes do grupo A, a taxa de concordância da sobrevida dos pacientes foi melhor (63,4\%) que o observado em pacientes do grupo B (30\%). Nossa amostra não teve nenhum paciente classificado como do grupo $C$.

Descritores: Coluna vertebral; Metástase neoplásica; Osso e ossos; Análise de sobrevida; Dados demográficos.

\section{RESUMEN}

Objetivo: El objetivo de este estudio es presentar datos demográficos sobre la aparición de metástasis en la columna vertebral en el servicio donde se realizó el trabajo e investigar la fiabilidad de la escala modificada de Tokuhashi en la toma de decisiones en pacientes con cáncer metastásico en la columna vertebral. Métodos: Se realizó una revisión retrospectiva de todos los casos de metástasis ósea vertebral, confirmados por examen histopatológico, de enero 2009 a junio de 2012. La revisión de los datos incluyó datos demográficos, origen del cáncer primario, duración de los síntomas, localización de las metástasis, escala de rendimiento de Karnofsky y el cálculo de la supervivencia basado en la escala modificada de Tokuhashi. Dividimos a los pacientes tres grupos. El grupo A incluyó pacientes con una esperanza de vida inferior a 6 meses, el grupo B incluyó pacientes con una esperanza de vida de entre seis y 12 meses y el grupo C incluyó pacientes con esperanza de vida superior a 12 meses. Se comparó la supervivencia calculada con la supervivencia actual en los tres grupos, con todos los pacientes seguidos a un mínimo de un año o hasta la muerte. Resultados: La supervivencia esperada en el grupo A fue de 63,6\%, según la escala modificada de Tokuhashi, pero los pacientes del grupo B tenían sólo un 30\% de concordancia. Conclusiones: En los pacientes del grupo A, la tasa de concordancia de la supervivencia del paciente fue mejor $(63,4 \%)$ que la observada en el grupo de pacientes en el grupo B (30\%). En nuestra muestra no había ningún paciente clasificado como grupo C.

Descriptores: Columna vertebral; Metástasis de la neoplasia; Huesos; Análisis de supervivencia; Dados demográficos. 


\section{INTRODUCTION}

Bone metastases are the most common skeletal tumors and the spine is the most common site of bone involvement. Skeletal metastases are produced by almost all forms of malignant disease, but they are most often secondary to breast, lung, and prostate cancer, and less frequently to kidney, thyroid, and gastrointestinal cancer. Multiple myeloma and lymphoma are the most common sources of disseminated bone lesions; however whether they are considered to be metastases or primary lesions varies from author to author. Lymphoreticular neoplasms, breast, lung and prostate account for approximately $60 \%$ of all vertebral tumors.

Vertebral metastasis should be considered a systemic disease with limited treatment methods. The spine surgeon with oncological knowledge should be able to prevent recurrence of the tumor, avoid neurological damage, and, above all, contribute to the quality of life of the patient until the last moment of life. Therefore, it is important to determine the mode of treatment according to the survival of the patient. Establishing the prognosis is one of the most important and decisive factors in selecting a therapeutic modality. Although non-surgical treatment is still an important option, surgical treatment with all its modalities should be considered.

In recent years, there has been a gradual change in the surgical treatment of metastatic spine cancer followed by oncological treatment. This has been made possible by prognostic scores, new surgical techniques, better chemotherapy and radiotherapy techniques, and recognition of the need to maintain mobility and control pain in this special group of patients. Survival is the most important parameter in the choice of treatment used. ${ }^{1}$ Many scores are used, including modified Tokuhashi and Tomita scores, ${ }^{2-4}$ included among some of the more important ones.

The objective of this study is to present demographic data about the occurrence of spinal metastases in the service where the study was conducted and to investigate the reliability of the modified Tokuhashi score in the decision-making process in patients with metastatic spinal cancer.

\section{METHODS}

We conducted a review of the medical records of 21 patients treated for metastatic spinal cancer during the period from January, 2009 to June, 2012. The oncological diagnoses of all patients were confirmed by positive anatomopathological biopsies.

The data review included demographic details, the primary source of the cancer, the duration of symptoms, the location of the metastases, a calculation of the Karnofsky performance status, ${ }^{5}$ and a calculation of survival based on the modified Tokuhashi score. The records of all the patients evaluated included magnetic resonance of the spine, computed tomography of the thorax and abdomen for staging, and bone scintigraphy for the evaluation of other skeletal lesions. Twelve of the patients evaluated underwent surgical stabilization, six underwent vetrebroplasty, and three were submitted to biopsies only for diagnostic confirmation and oncological treatment because of the stability of their lesions and the absence of progressive neurological damage. All of the surgeries were performed by one of three experienced spine surgeons and were followed up for a minimum period of a year or until the death of the patient.

The patients were divided into three groups as suggested by the modified Tokuhashi score. Group A included patients with life expectancy of less than 6 months, Group B included patients with life expectancy of between 6 and 12 months, and Group C with life expectancy greater than 12 months. We compared the survival predicted by the Tokuhashi score with the actual survival of the patients in the three groups during follow-up and up until death.

This study was approved by the Institutional Review Board of the Hospital do Servidor Público Estadual de São Paulo as CAAE protocol number 07562213.9.0000.5463 and the informed consent form was waived.

\section{RESULTS}

We evaluated 21 patients, 7 male and 14 female. The average age was 62.5 years (ranging from 43 to 82 years of age). The most common metastasis site was the thoracic spine ( 9 cases), followed by the lumbar spine (8 cases). No cases of isolated involvement of the cervical spine were encountered. Multiple regions were affected in four cases. The breast was the most frequent focus of the primary tumor, with five cases. There were three cases of hematological origin, two of prostate, and two cases of neoplasia of the colon. Other sites such as the kidney, lung, uterus, bile ducts, liver, stomach, esophagus, rectum, and ovaries had one case each. (Table 1)

Of the cases studied, twelve underwent posterior approach surgical stabilization, six vertebroplasty, and three transpedicular needle biopsy followed by non-surgical oncological treatment. Results of the Karnofsky performance status calculation yielded thirteen patients in the 0-50 category, eight in the 50-70 category, and none in the $>70$ category. Life expectancy, calculated using the modified Tokuhashi score, assigned eleven patients to Group A, ten to Group B, and none to Group C. Of the 21 patients, ten survived less than 6 months, six between 6 and 12 months, and 5 survived at least 12 months following surgery. Nine patients presented neurological deficit in follow-ups. (Table 2)

Among the patients in Tokuhashi Group A, seven (63.6\%) survived less than 6 months, three (27.2\%) between 6 and 12 months, and one (9\%) survived more than 12 months. In Group B, three patients (30\%) survived for the period predicted by the Tokuhashi score, three (30\%) survived for less than 6 months, and four (40\%) survived for more than 12 months. None of the patients was classified as Group C.

Table 1. Type of tumor.

\begin{tabular}{c|c|c}
\hline Type of tumor & Number of patients & $\%$ \\
\hline Kidney & 1 & 4.7 \\
\hline Prostate & 2 & 9.5 \\
\hline Hematological & 3 & 14.2 \\
\hline Breast & 5 & 23.8 \\
\hline Lung & 1 & 4.7 \\
\hline Gastrointestinal tract & 7 & 33 \\
\hline Uterus & 1 & 4.7 \\
\hline Ovary & 1 & 4.7 \\
\hline Total & 21 & 100
\end{tabular}

Table 2. Correlation between clinical variables and current survival.

\begin{tabular}{c|c|c|c}
\hline \multirow{2}{*}{ Variables } & \multicolumn{3}{|c}{ Current survival } \\
\cline { 2 - 4 } & $\begin{array}{c}<\mathbf{6} \text { months } \\
(\mathbf{n}=\mathbf{1 0})\end{array}$ & $\begin{array}{c}\mathbf{6 - 1 2} \text { months } \\
(\mathbf{n}=\mathbf{6})\end{array}$ & $\begin{array}{c}>\mathbf{1 2} \text { months } \\
\text { (n= 5) }\end{array}$ \\
\hline Sex & 5 & 0 & 2 \\
\hline Male & 5 & 6 & 3 \\
\hline Female & & & 2 \\
\hline Age & 6 & 2 & 3 \\
\hline$<60$ years & 4 & 4 & 1 \\
\hline$>60$ years & & & 4 \\
\hline Karnofsky & 9 & 3 & 0 \\
\hline$<50$ & 1 & 3 & \\
\hline $51-70$ & 0 & 0 & \\
\hline$>70$ & & & \\
\hline Modified Tokuhashi score & 7 & 3 & \\
\hline Group A (0-8) & 3 & 3 & \\
\hline Group B (9-12) & 0 & 0 & \\
\hline Group C (13-15) & & & \\
\hline Neurological damage & & 3 & \\
\hline No & 4 & 3 & \\
\hline Yes & 6 & & \\
\hline
\end{tabular}




\section{DISCUSSION}

There are many recommendations for choosing the best treatment method for patients with metastatic bone tumors of the spine. Many studies suggest that choosing surgical treatment depends on the type of primary tumor, the extent of the disease, destruction of the bone, and the neurological compromise.$^{6-9}$ However, it was only after the work of Tokuhashi that life expectancy was considered to be the most important criterion in treatment selection.

Based on our evaluation, 52.4\% (eleven patients) had survival different from that predicted by the Tokuhashi score, while $47.6 \%$ (ten patients) survived in accordance with that predicted by the modified Tokuhashi score.

In Tokuhashi's original article and in that where he presents the modified score, lymphoma and myeloma were excluded as causes of bone metastasis. However, Choi et al. ${ }^{10}$ suggested the inclusion of myeloma and lymphoma as common causes of metastatic bone tumors of the spine.

In 2005, Tokuhashi et al. ${ }^{3}$ proposed their modified score and applied it retrospectively to 246 patients, resulting in a concordance of $75 \%$ in all the groups. In the retrospective analysis of our data, we observed that $63.6 \%$ of the patients in Group A had survival that agreed with that predicted by the modified Tokuhashi score and were treated conservatively or with palliative surgery. Thus, in $36.4 \%$ of the cases included in Group A, there was no concordance with the survival predicted by the score, but survival was longer than expected. These patients were treated with palliative surgery.
In terms of the patients in Group B, only $30 \%$ had the survival predicted by the score, all of whom underwent palliative surgery. There was a discordance of $70 \%$ in the survival observed in these patients in relation to that predicted, with 30\% living for a shorter time than expected and $40 \%$ living longer.

The modified Tokuhashi score is useful and widely used in the therapeutic decision-making process. However, it has not been shown to be accurate in determining survival. ${ }^{11}$ This study obtained results that agree with the described lack of precision in determining the survival of patients affected by metastatic spinal disease. For the patients in Group A, the survival concordance rate was better (63.4\%) than that observed in patients in Group B (30\%). Our sample had no patient classified by the Tokuhashi score as Group C.

\section{CONCLUSIONS}

We present the demographic results of 21 patients with anatomopathologically confirmed metastatic disease of the spine. These patients were classified according to the Tokuhashi score and current survival was compared with that predicted by the score. For the patients in Group A, the survival concordance rate was better $(63.4 \%)$ than that observed in the patients in Group B. Our sample had no patients classified as Group C by the Tokuhashi score.

All the authors declare that there are no potential conflicts of interest regarding this article.

CONTRIBUTIONS OF THE AUTHORS: Each author made significant individual contributions to the development of the manuscript. DMD and RRP were the main contributors to the writing of the manuscript. DMD and ALPF collected the clinical and medical report data of the cases studied. DMD, RRP, and CEASO conducted the bibliographical research, analyzed the statistical data, discussed the study results, reviewed the manuscript, and contributed to the intellectual concept of the study.

\section{REFERENCES}

1. Pointillart V, Vital JM, Salmi R, Diallo A, Quan GM. Survival prognostic factors and clinical outcomes in patients with spinal metastases. J Cancer Res Clin Oncol. 2011;137(5):849-56.

2. Tokuhashi Y, Matsuzaki H, Toriyama S, Kawano H, Ohsaka S. Scoring system for the preoperative evaluation of metastatic spine tumor prognosis. Spine (Phila Pa 1976). 1990;15(11):1110-3.

3. Tokuhashi Y, Matsuzaki H, Oda H, Oshima M, Ryu J. A revised scoring system for preoperative evaluation of metastatic spine tumor prognosis. Spine (Phila $\mathrm{Pa}$ 1976). 2005;30(19):2186-91.

4. Tomita K, Kawahara N, Kobayashi T, Yoshida A, Murakami H, Akamaru T. Surgical strategy for spinal metastases. Spine (Phila Pa 1976). 2001;26(3):298-306.

5. Karnofsky DA. Clinical evaluation of anticancer drugs. In: Cancer chemotherapy. Gann Monograph. 1967;2:223-31.

6. Enkaoua EA, Doursounian L, Chatellier G, Mabesoone F, AimardT, Saillant G. Vertebral metastases: a critical appreciation of the preoperative prognostic tokuhashi score in a series of 71 cases. Spine (Phila Pa 1976). 1997;22(19):2293-8.
7. Constans JP, de Divitiis E, Donzelli R, Spaziante R, Meder JF, Haye C. Spinal metastases with neurological manifestations. Review of 600 cases. J Neurosurg. 1983;59(1):111-8.

8. Mardjetko SM, Hammerberg KW, Lubicky JP, Fister JS. The Luque trolley revisited. Review of nine cases requiring revision. Spine (Phila Pa 1976). 1992;17(5):582-9.

9. Harrington KD. Metastatic disease of the spine. J Bone Joint Surg Am. 1986;68(7):1110-5.

10. Choi D, Crockard A, Bunger C, Harms J, Kawahara N, Mazel C, et al. Review of metastatic spine tumour classification and indications for surgery: the consensus statement of the Global Spine Tumour Study Group. Eur Spine J. 2010;19(2):215-22.

11. Gakhar H, Swamy GN, Bommireddy R, Calthorpe D, Klezl Z. A study investigating the validity of modified Tokuhashi score to decide surgical intervention in patients with metastatic spinal cancer. Eur Spine J. 2013;22(3):565-8. 